\title{
A proposed mechanism for the ammonia-LCFA synergetic co-inhibition effect on anaerobic digestion process
}

Tian, Hailin; Karachalios, Panagiotis; Angelidaki, Irini; Fotidis, loannis

Published in:

Chemical Engineering Journal

Link to article, DOI:

10.1016/j.cej.2018.05.083

Publication date:

2018

Document Version

Peer reviewed version

Link back to DTU Orbit

Citation (APA):

Tian, H., Karachalios, P., Angelidaki, I., \& Fotidis, I. (2018). A proposed mechanism for the ammonia-LCFA synergetic co-inhibition effect on anaerobic digestion process. Chemical Engineering Journal, 349, 574-580. https://doi.org/10.1016/j.cej.2018.05.083

\section{General rights}

Copyright and moral rights for the publications made accessible in the public portal are retained by the authors and/or other copyright owners and it is a condition of accessing publications that users recognise and abide by the legal requirements associated with these rights.

- Users may download and print one copy of any publication from the public portal for the purpose of private study or research.

- You may not further distribute the material or use it for any profit-making activity or commercial gain

- You may freely distribute the URL identifying the publication in the public portal 


\section{Accepted Manuscript}

A proposed mechanism for the ammonia-LCFA synergetic co-inhibition effect on anaerobic digestion process

Hailin Tian, Panagiotis Karachalios, Irini Angelidaki, Ioannis A. Fotidis

PII:

$$
\text { S1385-8947(18)30897-0 }
$$

DOI: https://doi.org/10.1016/j.cej.2018.05.083

Reference: CEJ 19099

To appear in:

$$
\text { Chemical Engineering Journal }
$$

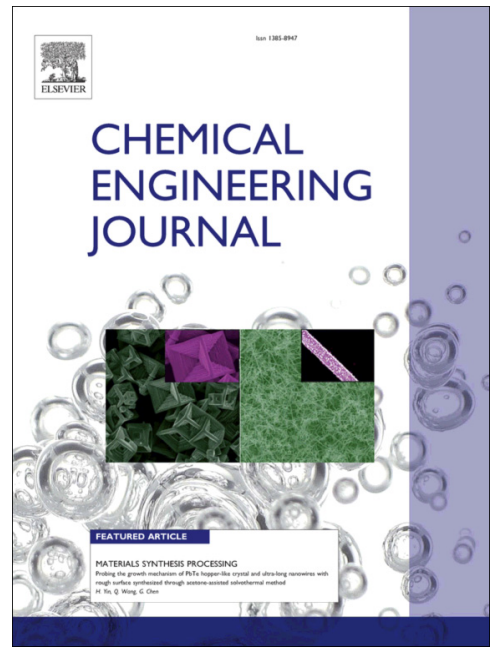

Received Date: 6 March 2018

Revised Date: $\quad 9$ May 2018

Accepted Date: 13 May 2018

Please cite this article as: H. Tian, P. Karachalios, I. Angelidaki, I.A. Fotidis, A proposed mechanism for the ammonia-LCFA synergetic co-inhibition effect on anaerobic digestion process, Chemical Engineering Journal (2018), doi: https://doi.org/10.1016/j.cej.2018.05.083

This is a PDF file of an unedited manuscript that has been accepted for publication. As a service to our customers we are providing this early version of the manuscript. The manuscript will undergo copyediting, typesetting, and review of the resulting proof before it is published in its final form. Please note that during the production process errors may be discovered which could affect the content, and all legal disclaimers that apply to the journal pertain. 


\section{A proposed mechanism for the ammonia-LCFA synergetic co-}

\section{inhibition effect on anaerobic digestion process}

Hailin Tian, Panagiotis Karachalios, Irini Angelidaki, Ioannis A. Fotidis *

Department of Environmental Engineering, Technical University of Denmark, Bygningstorvet Bygning 115, DK-2800 Kgs. Lyngby, DK

*Corresponding Author: Ioannis A. Fotidis, Department of Environmental Engineering, Technical University of Denmark, Bygningstorvet Bygning 115, DK-2800 Kgs. Lyngby, Denmark, Phone: (+45) 45251418; Fax: (+45) 45933850; e-mail: ioanf@env.dtu.dk 


\section{Abstract}

Ammonia and long chain fatty acids (LCFA) are two major inhibitors of the anaerobic digestion (AD) process. The individual inhibitory effect of each of these two inhibitors is well established; however, the combined co-inhibition effect has not been thoroughly assessed yet. In the current study, the ammonia-LCFA synergetic coinhibition effect was investigated in both batch and continuous experiments. In the batch experiments, a clear ammonia-LCFA synergetic co-inhibitory effect was identified when the LCFA concentrations were higher than $0.05 \mathrm{~g}$ oleate $\mathrm{L}^{-1}$ and ammonia levels between 4.0 and $7.0 \mathrm{NH}_{4}{ }^{+}-\mathrm{N} \mathrm{L}^{-1}$. This synergetic effect for LCFA and ammonia levels above $1.1 \mathrm{~g}$ oleate $\mathrm{L}^{-1}$ and $4.5 \mathrm{NH}_{4}^{+}-\mathrm{N} \mathrm{L}^{-1}$, respectively, was validated in continuous reactors experiments. Nevertheless, adaptation of the AD microbiome to this synergetic co-inhibition could occur after a period of continuous operation. A potential mechanism to explain the synergetic co-inhibition lies on the initial inhibition of methanogens caused by ammonia resulting in increased VFA and hydrogen concentrations, which in turn renders $\beta$-oxidation of LCFA thermodynamically unfavourable and thereby brings about further excess accumulation of LCFA and consequently higher unspecific toxicity of all AD steps. This is a vicious cycle, which makes the combined inhibition of the two toxicants more severe, compared to the sum of their individual inhibition effects at the same operational conditions.

\section{Keywords}

Anaerobic microbiome; Batch reactors; CSTR reactors; Methane; Toxicity. 


\section{Introduction}

Anaerobic digestion (AD) is a widely used sustainable technology for bioenergy $\left(\mathrm{CH}_{4}\right)$ recovery from a variety of biowastes and wastewaters, such as industrial wastewater, agricultural and forestry residues, municipal sewage sludge etc. [1,2]. It is a complex biological process, consisting of four steps, i.e. hydrolysis, acidogenesis, acetogenesis and methanogenesis, which are mediated by different groups of microorganisms [3]. However, these microorganisms can be easily inhibited by different compounds contained and/or released from the substrate degradation, such as ammonia, long chain fatty acids (LCFA), heavy/light metals, sulphide, etc., which result in $\mathrm{AD}$ process instability with suboptimal methane production $[4,5]$. Amongst ammonia and LCFA are the two most common and major inhibitors of AD process.

Total ammonia (TAN), consisting of ammonium ions $\left(\mathrm{NH}_{4}{ }^{+}\right)$and free ammonia (FAN, $\mathrm{NH}_{3}$ ), is produced during anaerobic degradation of proteins, urea, and nucleic acids [6]. It is a basic nutrient for microorganism growth at concentrations below 200 $\mathrm{mg} \mathrm{NH}_{4}{ }^{+}-\mathrm{N} \mathrm{L}^{-1}$ [7]. However, it was reported by many researchers (reviewed by Chen, et al. [5]) that concentrations ranging from 1.7 to $14 \mathrm{~g} \mathrm{NH}_{4}{ }^{+}-\mathrm{N} \mathrm{L}^{-1}$ inhibit the methanogenic activity depending on different experimental conditions. Furthermore, FAN, which increases alongside $\mathrm{pH}$ and temperature, is believed to be the most toxic ammonia form [8]. Reduction of growth rate by $50 \%$ on aceticlastic and hydrogenotrophic methanogens happened at 280 and $520 \mathrm{mg} \mathrm{NH}_{3}-\mathrm{N} \mathrm{L}^{-1}$, respectively [9]. Moreover, Benabdallah El Hadj, et al. [10] demonstrated that 50\% inhibition on methane production of municipal solid waste was observed at $468 \mathrm{mg} \mathrm{NH}_{3}-\mathrm{N} \mathrm{L}^{-1}$ under thermophilic condition. However, adaptation of the microbial community to high ammonia levels after a long period of operation was reported, for example, the 
methanogenic activity remained efficient at FAN levels of $800 \mathrm{mg} \mathrm{NH}_{3}-\mathrm{N} \mathrm{L}^{-1}$ in a upflow anaerobic sludge blanket (UASB) reactor [11], and $1500 \mathrm{mg} \mathrm{NH}_{3}-\mathrm{N} \mathrm{L}^{-1}$ in a fedbatch reactor [12]. It has been proposed that ammonia inhibition occurs when ammonia enters into cytoplasma where it is ionised by taking up a proton, which is balanced by exporting a potassium ion and thereby causing potassium deficiency $[13,14]$.

LCFA are the intermediate products of lipids' hydrolysis, thus are abundant in lipidrich substrates such as slaughterhouse wastewater and dairy industrial sludge $[15,16]$. Lipid-rich biomasses are attractive $\mathrm{AD}$ feedstocks due to their high methane yield potential of up to $1014 \mathrm{~mL} \mathrm{CH}_{4} \mathrm{~g}^{-1}$ VS [3]. LCFA (e.g. oleic acid (Eq. (1)) are degraded through $\beta$-oxidation [17], forming acetate, hydrogen and shorter chain fatty acids, which are further catabolized to acetate and hydrogen (Eq. (2)) after several cycles of $\beta$ oxidation [18]. This $\beta$-oxidation process is regarded as the rate limiting step of LCFA degradation due to its slow degradation rate [19]. Furthermore, LCFA can be attached on the cell membrane and limit the mass transfer [20], and thus inhibit the activities of the microorganisms involved in all the AD steps [21]. It was reported that LCFA concentration of $0.2 \mathrm{~g}$ oleate $\mathrm{L}^{-1}$ already had a profound inhibitory effect and biogas production ceased at $0.5 \mathrm{~g}$ oleate $\mathrm{L}^{-1}$ [22]. Hwu, et al. [23] reported 50\% inhibition of methanogenesis in batch reactors at $0.1-0.9 \mathrm{~g}$ oleate $\mathrm{L}^{-1}$, depending on the origin of the different inocula. However, many studies have reported an adaptation of the microbial communities during the degradation of LCFA. For example, Palatsi, et al. [24] reported that after 50 days of adaptation to successive LCFA pulses in semi-continuous reactors, the aceticlastic and hydrogenotrophic methanogenic activity was improved by $8 \%$ and $62 \%$, respectively. Furthermore, almost twofold higher tolerance to LCFA levels was found when Alves, et al. [25] used inoculum derived from a lipids fed reactor compared 
to inoculum from a non-lipids fed reactor. The adaptation of the AD process to LCFA is attributed to the development of a larger pool of LCFA degrading bacteria, which are responsible for keeping the LCFA low, and thereby prevent of reaching LCFA inhibitory levels.

$$
\begin{aligned}
& \mathrm{C}_{18} \mathrm{H}_{33} \mathrm{O}_{2}^{-}+2 \mathrm{H}_{2} \mathrm{O} \rightarrow \mathrm{C}_{16} \mathrm{H}_{29} \mathrm{O}_{2}^{-}+\mathrm{CH}_{3} \mathrm{COO}^{-}+2 \mathrm{H}_{2}+\mathrm{H}^{+} \quad \Delta \mathrm{G}^{0}=50.50 \mathrm{~kJ} \mathrm{~mol}^{-1} \text { Eq. (1) } \\
& \mathrm{C}_{18} \mathrm{H}_{33} \mathrm{O}_{2}^{-}+16 \mathrm{H}_{2} \mathrm{O} \rightarrow 9 \mathrm{CH}_{3} \mathrm{COO}^{-}+15 \mathrm{H}_{2}+8 \mathrm{H}^{+} \quad \Delta \mathrm{G}^{0}=390.85 \mathrm{~kJ} \mathrm{~mol}^{-1} \quad \text { Eq. (2) }
\end{aligned}
$$

Up to date, many studies have assessed the individual inhibitory effect of either ammonia or LCFA on AD process $[4,24,26,27]$. However, only few reports can be found assessing the combined inhibitory effect of the two inhibitors. Some researchers have suggested that different inhibitory factors might have a synergetic co-inhibition effect on the AD process [5], which is defined as the interaction or cooperation of two or more factors that can produce a combined effect greater than the sum of their individual effects [28]. Recently, Wang, et al. [29] reported a potential ammonia-LCFA synergetic co-inhibition effect in manure-based continuous reactors. However, no clear conclusions of that study could be derived as were based on the comparison between two manure-fed continuous reactors with ammonia or ammonia and LCFA (glycerol trioleate-GTO) added in their feedstocks; while a reactor fed only with LCFA was missing. Moreover, the mechanism behind the synergistic inhibition could not be elucidated. Therefore, a dedicated study, in both batch and continuous reactors, to completely assess and define the potential ammonia-LCFA synergetic co-inhibition is necessary. 
The aim of this study was to assess the possibility of a synergetic co-inhibition effect of ammonia and LCFA on AD process and to propose a potential mechanism that creates the synergism. To achieve this aim, firstly, three batch experimental assays were performed to compare the individual and the combined inhibitory effect of ammonia and LCFA. Secondly, a continuous reactors experiment was set to investigate the coinhibition effect under different ammonia and LCFA levels and identify any potential adaption of the methanogenic microbiome to the synergetic co-inhibition effect.

\section{Material and methods}

\subsection{Inoculum and feedstock}

The inoculum used in this study was derived from a manure based full-scale thermophilic $\left(53 \pm 1^{\circ} \mathrm{C}\right)$ biogas plant (Snertinge, Denmark). It was flushed with pure $\mathrm{N}_{2}$ gas after arriving in the lab, and used immediately to start up the continuous reactors. For batch experiment, prior to use, the inoculum was kept in a thermophilic incubator $\left(55 \pm 1^{\circ} \mathrm{C}\right)$ for one week to reduce the background methane production. Cattle manure, obtained from Hashøj municipality in Denmark, was used as the main feedstock in all the experiments. After sieving (1 mm diameter) the manure to separate the large particles, it was stored at $-21^{\circ} \mathrm{C}$, and thawed at $4{ }^{\circ} \mathrm{C}$ for $2-3$ days before use. Moreover, biochemical methane potential (BMP) of the cattle manure $\left(271.44 \pm 23.36 \mathrm{~mL} \mathrm{~g}^{-1} \mathrm{VS}\right.$, supplementary material Fig.S1) was defined according to a previously proposed protocol [30]. The basic characteristics of the inoculum and feedstock are depicted in Table 1. Furthermore, ammonium chloride $\left(\mathrm{NH}_{4} \mathrm{Cl}\right.$, purity $\geq 99.5 \%$, Sigma-Aldrich, CAS: $12125-02-9)$ and sodium oleate $\left(\mathrm{C}_{18} \mathrm{H}_{33} \mathrm{NaO}_{2}\right.$, purity $\geq 82 \%$, Sigma-Aldrich, CAS: 143-19-1) were chosen as ammonia and LCFA sources, respectively. 


\subsection{Batch experiment setup}

Three different batch assays (i.e. Assay I: ammonia inhibition test, Assay II: LCFA inhibition test, and Assay III: ammonia + LCFA inhibition test) were performed using glass serum bottles with 40 and $118 \mathrm{~mL}$ working and total volume, respectively. In each bottle, $35 \mathrm{~mL}$ inoculum, $2.7 \mathrm{~mL}$ cattle manure (reaching final organic load of the reactor1.0 $\mathrm{g} \mathrm{VS} \mathrm{L}^{-1}$ ) and $2.3 \mathrm{~mL}$ distilled water were added. Then the amount of $\mathrm{NH}_{4} \mathrm{Cl}$ and LCFA were added according to the different designed levels. In total, four TAN levels, six LCFA levels and 12 combined TAN+LCFA levels were tested in the batch assays (Table 2). The $\mathrm{pH}$ was adjusted to $8.0 \pm 0.1$ using $\mathrm{HCl}$ or $\mathrm{NaOH}$ solutions. After sealing with butyl rubber stoppers and aluminium caps, and flushing with $\mathrm{N}_{2}$ gas, all bottles were incubated at $55 \pm 1^{\circ} \mathrm{C}$ for 42 days. All experiments were performed in triplicates.

\subsection{Continuous experiment setup}

Three lab-scale thermophilic $\left(53 \pm 1^{\circ} \mathrm{C}\right)$ continuously stirrer tank reactors (CSTR) were used in this study, named $\mathrm{R}_{\mathrm{TAN}}$ (ammonia inhibition test), $\mathrm{R}_{\mathrm{LCFA}}$ (LCFA inhibition test) and $\mathrm{R}_{\mathrm{COM}}(\mathrm{TAN}+\mathrm{LCFA}$ combined inhibition test). Each reactor had a 1.8 and $2.3 \mathrm{~L}$ working and total volume, respectively, and was equipped with an influent and an effluent bottle, a feeding peristaltic pump, an electrical heating jacket, a waterdisplacement gas meter and two magnetic stirrers. The hydraulic retention time (HRT) was set to 15 days. To keep a constant organic loading rate (OLR) of $1.0 \mathrm{~g} \mathrm{VS} \mathrm{L}^{-1} \mathrm{~d}^{-1}$ throughout the experiment and avoid any organic overloading effect, the corresponding amount of VS was removed from both the feedstock and the reactor when LCFA were fed in the reactors. The experiment was divided into five phases, and the operational 
parameters in each of these phases are presented in Table 3. At the beginning of each new phase, TAN and/ or LCFA levels were increased instantly both inside the reactor and in the feedstock.

\subsection{Analyses}

TS, VS, TKN and TAN were measured according to standard method of APHA [31]. A PHM99 LAB pH meter was used for $\mathrm{pH}$ measurement [26]. VFA concentration was measured by a gas-chromatograph (HP 5890 series II) using nitrogen as carried gas, and equipped with flame ionization detector and a FFAP fused silica capillary column (30 $\mathrm{m} \times 0.53 \mathrm{~mm}$ i.d., film thickness $1.5 \mu \mathrm{m})$ [32]. Moreover, methane content was determined by a gas-chromatograph (Trace 1310 GC-TCD, Thermo Fisher, Denmark) equipped with TracePLOT TG-BOND Q 26004-6030 column (30 m × 0.32 mm I.D., film thickness $10.0 \mu \mathrm{m})$ (Thermo Fisher), and helium as carrier gas [12].

\subsection{Calculations and statistics}

\subsubsection{Relative methane production and synergetic co-inhibition effect}

In batch assays, the methane production derived from the reactors that contained only cattle manure (without the addition of ammonia and LCFA) was used as the baseline production. For the batch reactors that ammonia but no LCFA was added, the maximum methane production was equal to the baseline production. While for reactors with LCFA addition, the maximum expected methane production was calculated by summing up the batch baseline production and the theoretically maximum methane production from the added LCFA $\left(1014 \mathrm{~mL} \mathrm{CH}_{4} \mathrm{~g}^{-1} \mathrm{VS}\right)$. Finally, the inhibition effect (I, expressed as \%) was defined as the difference between the calculated maximum (Bo) 
and practical methane production $\left(\mathrm{B}_{\mathrm{pr}}\right)$ of each reactor, divided by the calculated maximum production $\left(\mathrm{B}_{\mathrm{o}}\right)$.

$$
\mathrm{I}=\left(\mathrm{B}_{\mathrm{o}}-\mathrm{B}_{\mathrm{pr}}\right) / \mathrm{B}_{\mathrm{o}} * 100
$$

For the continuous reactors, the maximum methane production (Bo) was calculated by summing up the production from the cattle manure $\left(271 \mathrm{~mL} \mathrm{CH}_{4} \mathrm{~g}^{-1} \mathrm{VS}\right)$ and the production from LCFA (1014 $\left.\mathrm{mL} \mathrm{CH}_{4} \mathrm{~g}^{-1} \mathrm{VS}\right)$ based on the different proportion for each one of the different experimental phases. Thus, the relative methane $\left(\mathrm{B}_{\text {rel }}\right)$ production (expressed as \%) was defined as the ratio between practical methane production $\left(\mathrm{B}_{\mathrm{pr}}\right)$ and the maximum methane production $\left(\mathrm{B}_{\mathrm{o}}\right)$.

$$
\mathrm{B}_{\mathrm{rel}}=\mathrm{B}_{\mathrm{pr}} / \mathrm{B}_{\mathrm{o}} * 100
$$

Moreover, the relative methane production at $\mathrm{P} 1$ was used as the baseline to evaluate the inhibition in the other experimental phases (P2-P5).

The synergetic co-inhibition effect was assessed by comparing the practical inhibition effect of the TAN+LCFA combined reactors to the theoretically expected inhibition, which was calculated from the sum of the individual inhibition of the TAN and LCFA individual inhibition reactors under the same tested conditions.

\subsubsection{Statistical analyses}

One-way ANOVA was used to compare the significant difference $(p<0.05)$ between different toxicity levels, while two-way ANOVA was applied to identify the significant interaction $(p<0.05)$ between the two inhibitors. All statistical analyses and the plotted data were made with the OriginLab program (OriginLab Corporation, Northampton, Massachusetts).

\section{Results and discussion}




\subsection{Batch reactors experiments}

\subsubsection{Ammonia (Assay I) and LCFA (Assay II) individual inhibition tests}

The individual inhibition effect of both ammonia and LCFA increased $(p<0.05)$ alongside the inhibitors' levels (Fig. 1), which was in accordance with many previous studies [7, 21, 33]. In Assay I, less than $10 \%$ inhibition was observed at $4.0 \mathrm{NH}_{4}^{+}-\mathrm{N} \mathrm{L}^{-1}$, while above $40 \%$ inhibition was found at the highest tested TAN levels $\left(7.0 \mathrm{NH}_{4}{ }^{+}-\mathrm{N} \mathrm{L}^{-}\right.$ $\left.{ }^{1}\right)$. Similar results were reported by many researchers, for example, Angelidaki and Ahring [34] identified $4.0 \mathrm{~g} \mathrm{NH}_{4}^{+}-\mathrm{N} \mathrm{L}^{-1}$ as the inhibition threshold for continuous thermophilic digestion of cattle manure. Furthermore, Fotidis, et al. [33] reported that, in batch reactors experiments, no significant inhibition was detected when TAN levels were below $3.0 \mathrm{~g} \mathrm{NH}_{4}{ }^{+}-\mathrm{N} \mathrm{L}^{-1}$, while around $50 \%$ inhibition on the growth rate of methanogens was observed at $7.0 \mathrm{~g} \mathrm{NH}_{4}{ }^{+}-\mathrm{N} \mathrm{L}^{-1}$.

In Assay II, only $20 \%$ inhibition was found for $2.5 \mathrm{~g}$ oleate $\mathrm{L}^{-1}$ while complete inhibition occurred at $4.0 \mathrm{~g}$ oleate $\mathrm{L}^{-1}$. However, Angelidaki and Ahring [22] and Hwu, et al. [23] have reported 50 to $100 \%$ inhibition on methanogenesis at LCFA concentrations between 0.1 and $0.9 \mathrm{~g}$ oleate $\mathrm{L}^{-1}$ depending on the origin of tested inocula. This indicates that the inoculum used in the current study had a higher tolerance to LCFA toxicity levels compared to the inocula used in the aforementioned studies. A possible explanation could be the higher inoculum/working volume ratio $(87.5 \%, \mathrm{v} / \mathrm{v})$ of this study, compared to the aforementioned studies $(2-5 \%, \mathrm{v} / \mathrm{v})$, since increasing biomass/LCFA ratio seems to alleviate, to some extent, the LCFA inhibition effect [35].

\subsubsection{Ammonia + LCFA combined inhibition test (Assay III)}


The combined inhibition experiment results (Fig. 2) showed a clear $(p<0.05)$ ammonia-LCFA synergetic co-inhibition effect for LCFA levels higher than $0.05 \mathrm{~g}$ oleate $\mathrm{L}^{-1}$ and TAN levels between 4.0 and $7.0 \mathrm{~g} \mathrm{NH}_{4}{ }^{+}-\mathrm{N} \mathrm{L}^{-1}$. This synergetic coinhibition effect could be attributed to both the thermodynamically unfavourable $\beta$ oxidation of LCFA $\left(\Delta \mathrm{G}^{0}>0\right)$ and the different inhibition mechanisms of ammonia and LCFA. Specifically, the anaerobic degradation of LCFA relies on $\beta$-oxidation to form acetate and shorter chain fatty acids (Eq. (1-2)), which is endothermic and nonspontaneous at standard conditions. However, $\beta$-oxidation can become thermodynamically favourable $\left(\Delta \mathrm{G}^{0}<0\right)$ at reactor conditions when it couples with methanogenesis [36] resulting in lowering the hydrogen partial pressure. Ammonia is inhibiting mainly the methanogens. Therefore, when ammonia inhibits methanogenic activity, the hydrogen concentration would increase making the LCFA degradation not favourable and lead to excess LCFA accumulation. The LCFA inhibit more unspecific and are toxic to all microbial groups mediate the AD process [4]. Therefore, a possible mechanism that explains the ammonia-LCFA synergetic co-inhibition effect is that inhibited methanogenesis mainly by ammonia renders $\beta$-oxidation of LCFA thermodynamically unfavourable. As a result, an excess LCFA accumulation occurs in the system, which further inhibits all AD process steps and creates the synergism.

Nevertheless, when the LCFA concentration was lower than 0.2 g oleate $\mathrm{L}^{-1}$, no synergetic effect was detected, independently of the ammonia levels. This indicates that LCFA levels below $0.2 \mathrm{~g}$ oleate $\mathrm{L}^{-1}$ had no additional inhibitory effect on the AD process. Similarly, no synergetic effect was observed at $7.0 \mathrm{~g} \mathrm{NH}_{4}{ }^{+}-\mathrm{N} \mathrm{L}^{-1}$, independently of the LCFA levels. This could be explained by the devastating toxicity that such extremely high ammonia levels could cause to all the AD processes and not 
only to methanogenesis. Therefore, any LCFA addition cannot enhance further the inhibition on the AD process. This is supported by Lü, et al. [37] and Niu, et al. [38] reporting that hydrolytic and acidogenic efficiency decreased when the TAN levels were higher than $6.5 \mathrm{~g} \mathrm{NH}_{4}{ }^{+}-\mathrm{N} \mathrm{L}^{-1}$.

\subsection{Continuous reactors experiment}

\subsubsection{Methane production efficiency}

The methane production of all the reactors during P1 was similar $(p>0.05)$, and around $60 \%$ of the theoretical maximum production was observed at the steady state (Fig. 3), which was defined by the methane production variation below $10 \%$ for at least ten consecutive days [32]. The difference between the experimental and theoretical production was mainly due to the finite digesting time in continuous reactors $[3,39]$.

During P2 and P3, the ammonia-LCFA synergetic co-inhibition effect was not observed, even though the overall production of all the reactors decreased due to the increased inhibitors levels. Specifically, alongside the increase of TAN levels, the relative methane production of $\mathrm{R}_{\mathrm{TAN}}$ dropped up to $30 \%$ compared to the baseline. This result was in accordance with previous studies reporting that methane production decreased by between $28.2 \%$ to $41.1 \%$ when TAN levels was increased from 2.1 to 4.0 $\mathrm{NH}_{4}^{+}-\mathrm{N} \mathrm{L}^{-1}$ [29], moreover, $31 \%$ production loss was found in a CSTR reactor with stepwise increased TAN levels up to $5.0 \mathrm{NH}_{4}{ }^{+}-\mathrm{N} \mathrm{L}^{-1}$ [40]. $\mathrm{R}_{\mathrm{LCFA}}$ and $\mathrm{R}_{\mathrm{COM}}$ performed similarly with only a small reduction of their methane production (10-22\%) compared to the baseline production. Palatsi, et al. [35] have also reported small methane production loses followed by fast recovery of the reactor production for LCFA concentrations below $1.0 \mathrm{~g}$ oleate $\mathrm{L}^{-1}$. 
However, a clear synergetic co-inhibition effect in $\mathrm{R}_{\mathrm{COM}}$, which lasted between 7 to 10 days, was detected immediately after the increase of ammonia and LCFA levels at $\mathrm{P} 4$ and P5. Specifically, at the beginning of $\mathrm{P} 4$, methane production of $\mathrm{R}_{\mathrm{COM}}$ was inhibited by more than $50 \%$ compared to the baseline phase, while no inhibition and less than $30 \%$ inhibition were found for $\mathrm{R}_{\mathrm{LCFA}}$ and $\mathrm{R}_{\mathrm{TAN}}$, respectively. The same pattern was repeated at the beginning of $\mathrm{P} 5$ where $\mathrm{R}_{\mathrm{COM}}$ lost almost $85 \%$ of its methane production for 15 consecutive days. At the same time, $R_{L C F A}$ was inhibited only for seven days with maximum $74 \%$ production loss and recovered rapidly, while $\mathrm{R}_{\text {TAN }}$ was inhibited only by $25 \%$ throughout P5. These results confirm Wang, et al. [41] who has first suggested a potential ammonia-LCFA synergetic co-inhibition effect in reactors fed with GTO and cattle manure. Overall, the ammonia-LCFA synergetic co-inhibition effect in CSTR reactors was identified at TAN levels higher than $4.5 \mathrm{~g} \mathrm{NH}_{4}^{+}-\mathrm{N} \mathrm{L}^{-1}$ and LCFA levels higher than $1.1 \mathrm{~g}$ oleate $\mathrm{L}^{-1}$.

Nevertheless, even though this synergetic co-inhibition was detected immediately after the increase of the two inhibitors levels, the microbiome in $\mathrm{R}_{\mathrm{COM}}$ showed the ability to recover from the co-inhibition and perform stably after a certain period of adaptation. This might be attributed to the potential adaptation ability of the microbial community to both high ammonia [32, 42] and LCFA [24, 25] levels, after a long-term continuous operation.

\subsubsection{VFA and $\mathrm{pH}$ variation}

The VFA variation of the three reactors (Fig. 4a) was consistent with the methane production results, and further verified the ammonia-LCFA synergetic co-inhibition effect. Specifically, VFA levels at P1 were around $300 \mathrm{mg} \mathrm{HAc} \mathrm{L}^{-1}$ for all the reactors. However, an increase of VFA up to $3000 \mathrm{mg} \mathrm{HAc}^{-1}$ was observed in $\mathrm{R}_{\mathrm{LCFA}}$ and $\mathrm{R}_{\mathrm{COM}}$ 
after the increase of inhibitors' levels. It is worthy to notice that a faster VFA accumulation was detected in $\mathrm{R}_{\mathrm{LCFA}}$ than $\mathrm{R}_{\mathrm{COM}}$, especially at $\mathrm{P} 4$ and $\mathrm{P} 5$. This could be explained by 1) slower $\beta$-oxidation of LCFA in $\mathrm{R}_{\mathrm{COM}}$ than $\mathrm{R}_{\mathrm{LCFA}}$ due to the thermodynamically unfavourable $\beta$-oxidation caused by severe methanogenesis inhibition from high ammonia levels, and 2) the excess LCFA accumulation and high ammonia levels in $\mathrm{R}_{\mathrm{COM}}$ created a synergism that affected more the $\mathrm{R}_{\mathrm{COM}}$ than the $\mathrm{R}_{\mathrm{LCFA}}$. Therefore, the VFA results also supported the proposed mechanism for the synergetic co-inhibition effect. Nevertheless, the VFA levels in $\mathrm{R}_{\mathrm{COM}}$ decreased below $1500 \mathrm{mg} \mathrm{HAc} \mathrm{L}^{-1}$ after a certain period, which indicated adaptation of the microbiome to the synergetic effect. For $\mathrm{R}_{\mathrm{TAN}}$, a gradual increase of the VFA levels up to $1000 \mathrm{mg}$ HAc $\mathrm{L}^{-1}$ alongside the increase of the ammonia levels was observed as was expected [12, 43].

The $\mathrm{pH}$ varied between 7.6 and 8.0 during the steady state of each phase for all the reactors (Fig. 4b), which was within the optimal $\mathrm{pH}$ range for the AD process [44]. However, a distinct $\mathrm{pH}$ drop to around 7.3 was observed at the beginning of P4 and P5 in $\mathrm{R}_{\mathrm{LCFA}}$ and $\mathrm{R}_{\mathrm{COM}}$. This temporary $\mathrm{pH}$ drop was the result of the VFA accumulation $[45,46]$.

Overall, the synergetic co-inhibition effect was detected at specific LCFA and ammonia levels, in both batch and continuous reactors experiments and verified by the secondary analytical parameters (i.e. VFA and $\mathrm{pH}$ ). However, the concertation thresholds of ammonia and LCFA that cause this synergism were significantly different among the two reactor types. This could be attributed to the different ability that the microbiomes of CSTR and batch reactors have to resist inhibition under similar 
operational conditions (e.g. same: inoculum, incubation temperature, substrate, etc.) [12].

\section{Conclusions}

The current study showed a clear ammonia-LCFA synergetic co-inhibition effect in both batch and continuous AD reactors. The proposed mechanism for this synergy is that inhibition of methanogenesis, mainly due to high ammonia levels, slows down $\beta$ oxidation of LCFA, causing an excess LCFA accumulation, which further intensifies the overall AD process inhibition. The difference in the thresholds that cause this synergism between CSTR and batch reactors could be attributed to the different ability of the two reactor types to resist inhibition. However, a long-term exposure to moderate levels of ammonia and LCFA in continuous reactors could result in adaptation of the methanogenic microbiome and counteract the synergetic co-inhibition effect. Finally, the results also verified the significant role that ammonia and LCFA levels play in the $\mathrm{AD}$ process efficiency, and contribute to the optimized utilization of the nitrogen-rich and lipid-rich waste.

\section{Acknowledgements}

This work was supported by Energinet.dk under the project framework ForskEL

"MicrobStopNH $\mathrm{H}_{3}$-Innovative bioaugmentation strategies to tackle ammonia inhibition in anaerobic digestion process" (program no. 2015-12327). Hailin Tian would like to thank for the financial support from China Scholarship Council. The authors thank Hector Garcia for his technical support during the experiments.

\section{Appendix A. Supplementary material}


Supplementary data related to this article can be found at...

\section{References}

[1] K. Karim, R. Hoffmann, K. Thomas Klasson, M.H. Al-Dahhan, Anaerobic digestion of animal waste: Effect of mode of mixing, Water Res., 39 (2005) 3597-3606.

[2] M. Kamali, T. Gameiro, M.E.V. Costa, I. Capela, Anaerobic digestion of pulp and paper mill wastes - An overview of the developments and improvement opportunities, Chem. Eng. J., 298 (2016) 162-182.

[3] I. Angelidaki, D. Karakashev, D.J. Batstone, C.M. Plugge, A.J. Stams, Biomethanation and its potential, Methods Enzymol., 494 (2011) 327-351.

[4] J.L. Chen, R. Ortiz, T.W.J. Steele, D.C. Stuckey, Toxicants inhibiting anaerobic digestion: A review, Biotechnol. Adv., 32 (2014) 1523-1534.

[5] Y. Chen, J.J. Cheng, K.S. Creamer, Inhibition of anaerobic digestion process: a review, Bioresource Technology, 99 (2008) 4044-4064.

[6] R. Rajagopal, D.I. Massé, G. Singh, A critical review on inhibition of anaerobic digestion process by excess ammonia, Bioresour. Technol., 143 (2013) 632-641.

[7] T. Liu, S. Sung, Ammonia inhibition on thermophilic aceticlastic methanogens, Water Sci. Technol., 45 (2002) 113-120.

[8] D.I. Massé, R. Rajagopal, G. Singh, Technical and operational feasibility of psychrophilic anaerobic digestion biotechnology for processing ammonia-rich waste, Applied Energy, 120 (2014) 49-55.

[9] R. Borja, E. Sánchez, P. Weiland, Influence of ammonia concentration on thermophilic anaerobic digestion of cattle manure in upflow anaerobic sludge blanket (UASB) reactors, Process Biochem., 31 (1996) 477-483. 
[10] T. Benabdallah El Hadj, S. Astals, A. Gali, S. Mace, J. Mata-Alvarez, Ammonia influence in anaerobic digestion of OFMSW, Water Sci. Technol., 59 (2009) 1153-1158.

[11] B. Calli, B. Mertoglu, B. Inanc, O. Yenigun, Effects of high free ammonia concentrations on the performances of anaerobic bioreactors, Process Biochem., 40 (2005) 1285-1292.

[12] H. Tian, I.A. Fotidis, E. Mancini, I. Angelidaki, Different cultivation methods to acclimatise ammonia-tolerant methanogenic consortia, Bioresource Technology, 232 (2017) 1-9.

[13] C. Gallert, S. Bauer, J. Winter, Effect of ammonia on the anaerobic degradation of protein by a mesophilic and thermophilic biowaste population, Appl. Microbiol. Biotechnol., 50 (1998) 495-501.

[14] C. Wittmann, A.P. Zeng, W.D. Deckwer, Growth inhibition by ammonia and use of a pH-controlled feeding strategy for the effective cultivation of Mycobacterium chlorophenolicum, Appl. Microbiol. Biotechnol., 44 (1995) 519-525.

[15] U. Stoll, H. Gupta, MANAGEMENT STRATEGIES FOR OIL AND GREASE RESIDUES, Waste Manage. Res., 15 (1997) 23-32.

[16] L.-J. Wu, T. Kobayashi, H. Kuramochi, Y.-Y. Li, K.-Q. Xu, Y. Lv, High loading anaerobic co-digestion of food waste and grease trap waste: Determination of the limit and lipid/long chain fatty acid conversion, Chem. Eng. J., 338 (2018) 422-431.

[17] J.A. Lalman, D.M. Bagley, Anaerobic degradation and methanogenic inhibitory effects of oleic and stearic acids, Water Res., 35 (2001) 2975-2983.

[18] J.D.A. Lalman, Anaerobic degradation of linoleic (C18:2), oleic (C18:1) and stearic (C18:0) acids and their inhibitory effects on acidogens, acetogens and methanogens, in, National Library of Canada= Bibliothèque nationale du Canada, 2000. 
[19] S.-H. Kim, S.-K. Han, H.-S. Shin, Kinetics of LCFA Inhibition on Acetoclastic Methanogenesis, Propionate Degradation and $\beta$-Oxidation, J. Environ. Sci. Health, Pt. A: Toxic/Hazard. Subst. Environ. Eng., 39 (2004) 1025-1037.

[20] M.A. Pereira, O.C. Pires, M. Mota, M.M. Alves, Anaerobic biodegradation of oleic and palmitic acids: Evidence of mass transfer limitations caused by long chain fatty acid accumulation onto the anaerobic sludge, Biotechnol. Bioeng., 92 (2005) 15-23.

[21] D.G. Cirne, X. Paloumet, L. Björnsson, M.M. Alves, B. Mattiasson, Anaerobic digestion of lipid-rich waste-Effects of lipid concentration, Renewable Energy, 32 (2007) 965-975.

[22] I. Angelidaki, B.K. Ahring, Effects of free long-chain fatty acids on thermophilic anaerobic digestion, Appl. Microbiol. Biotechnol., 37 (1992) 808-812.

[23] C.-S. Hwu, B. Donlon, G. Lettinga, Comparative toxicity of long-chain fatty acid to anaerobic sludges from various origins, Water Sci. Technol., 34 (1996) 351-358.

[24] J. Palatsi, J. Illa, F.X. Prenafeta-Boldú, M. Laureni, B. Fernandez, I. Angelidaki, X. Flotats, Long-chain fatty acids inhibition and adaptation process in anaerobic thermophilic digestion: Batch tests, microbial community structure and mathematical modelling, Bioresour. Technol., 101 (2010) 2243-2251.

[25] M.M. Alves, J.A. Mota Vieira, R.M. Álvares Pereira, M.A. Pereira, M. Mota, Effects of lipids and oleic acid on biomass development in anaerobic fixed-bed reactors. Part II: Oleic acid toxicity and biodegradability, Water Res., 35 (2001) 264-270. [26] H. Tian, I.A. Fotidis, K. Kissas, I. Angelidaki, Effect of different ammonia sources on aceticlastic and hydrogenotrophic methanogens, Bioresource Technology, 250 (2018) 390-397. 
[27] H. Zheng, D. Li, M.S. Stanislaus, N. Zhang, Q. Zhu, X. Hu, Y. Yang, Development of a bio-zeolite fixed-bed bioreactor for mitigating ammonia inhibition of anaerobic digestion with extremely high ammonium concentration livestock waste, Chem. Eng. J. 280 (2015) 106-114.

[28] I. Lee, J.I. Han, The effects of waste-activated sludge pretreatment using hydrodynamic cavitation for methane production, Ultrasonics Sonochemistry, 20 (2013) $1450-1455$.

[29] H. Wang, I.A. Fotidis, I. Angelidaki, Ammonia-LCFA synergetic co-inhibition effect in manure-based continuous biomethanation process, Bioresour. Technol., 209 (2016) 282-289.

[30] C. Holliger, M. Alves, D. Andrade, I. Angelidaki, S. Astals, U. Baier, C. Bougrier, P. Buffiere, M. Carballa, V. de Wilde, F. Ebertseder, B. Fernandez, E. Ficara, I. Fotidis, J.C. Frigon, H.F. de Laclos, D.S. Ghasimi, G. Hack, M. Hartel, J. Heerenklage, I.S. Horvath, P. Jenicek, K. Koch, J, Krautwald, J. Lizasoain, J. Liu, L. Mosberger, M. Nistor, H. Oechsner, J.V. Oliveira, M. Paterson, A. Pauss, S. Pommier, I. Porqueddu, F. Raposo, T. Ribeiro, F. Rusch Pfund, S. Stromberg, M. Torrijos, M. van Eekert, J. van Lier, H. Wedwitschka, I. Wierinck, Towards a standardization of biomethane potential tests, Water Sci. Technol., 74 (2016) 2515-2522.

[31] APHA, Standard Methods for the Examination of Water and Wastewater, 22nd ed., American Public Health Association, American Water Works Association, Water Environment Federation, Washington DC, USA, 2012.

[32] H. Tian, I.A. Fotidis, E. Mancini, L. Treu, A. Mahdy, M. Ballesteros, C. GonzálezFernández, I. Angelidaki, Acclimation to extremely high ammonia levels in continuous 
biomethanation process and the associated microbial community dynamics, Bioresource Technology, 247 (2018) 616-623.

[33] I.A. Fotidis, D. Karakashev, T.A. Kotsopoulos, G.G. Martzopoulos, I. Angelidaki, Effect of ammonium and acetate on methanogenic pathway and methanogenic community composition, FEMS Microbiol Ecol, 83 (2013) 38-48.

[34] I. Angelidaki, B.K. Ahring, Thermophilic anaerobic digestion of livestock waste: the effect of ammonia, Appl. Microbiol. Biotechnol., 38 (1993) 560-564.

[35] J. Palatsi, M. Laureni, M.V. Andrés, X. Flotats, H.B. Nielsen, I. Angelidaki, Strategies for recovering inhibition caused by long chain fatty acids on anaerobic thermophilic biogas reactors, Bioresour. Technol., 100 (2009) 4588-4596.

[36] S.T. Oh, A.D. Martin, Long chain fatty acids degradation in anaerobic digester: Thermodynamic equilibrium consideration, Process Biochem., 45 (2010) 335-345. [37] F. Lü, M. Chen, P.-J. He, L.-M. Shao, Effects of ammonia on acidogenesis of protein-rich organic wastes, Environ. Eng. Sci., 25 (2008) 114-122.

[38] Q. Niu, W. Qiao, H. Qiang, T. Hojo, Y.-Y. Li, Mesophilic methane fermentation of chicken manure at a wide range of ammonia concentration: Stability, inhibition and recovery, Bioresour. Technol., 137 (2013) 358-367.

[39] H. Bouallagui, R. Ben Cheikh, L. Marouani, M. Hamdi, Mesophilic biogas production from fruit and vegetable waste in a tubular digester, Bioresour. Technol., 86 (2003) 85-89.

[40] I.A. Fotidis, L. Treu, I. Angelidaki, Enriched ammonia-tolerant methanogenic cultures as bioaugmentation inocula in continuous biomethanation processes, J. Cleaner Prod., 166 (2017) 1305-1313. 
[41] H. Wang, I.A. Fotidis, I. Angelidaki, Ammonia effect on hydrogenotrophic methanogens and syntrophic acetate-oxidizing bacteria, FEMS Microbiol. Ecol., 91 (2015).

[42] B. Calli, B. Mertoglu, B. Inanc, O. Yenigun, Methanogenic diversity in anaerobic bioreactors under extremely high ammonia levels, Enzyme and Microbial Technology, 37 (2005) 448-455.

[43] M. Westerholm, L. Leven, A. Schnurer, Bioaugmentation of syntrophic acetateoxidizing culture in biogas reactors exposed to increasing levels of ammonia, Appl Environ Microbiol, 78 (2012) 7619-7625.

[44] J.J. Lay, Y.Y. Li, T. Noike, The influence of $\mathrm{pH}$ and ammonia concentration on the methane production in high-solids digestion processes, Water Environ. Res., 70 (1998) 1075-1082.

[45] L. Zhang, D. Jahng, Long-term anaerobic digestion of food waste stabilized by trace elements, Waste Manage., 32 (2012) 1509-1515.

[46] L.N. Liew, J. Shi, Y. Li, Enhancing the solid-state anaerobic digestion of fallen leaves through simultaneous alkaline treatment, Bioresour. Technol., 102 (2011) 88288834. 


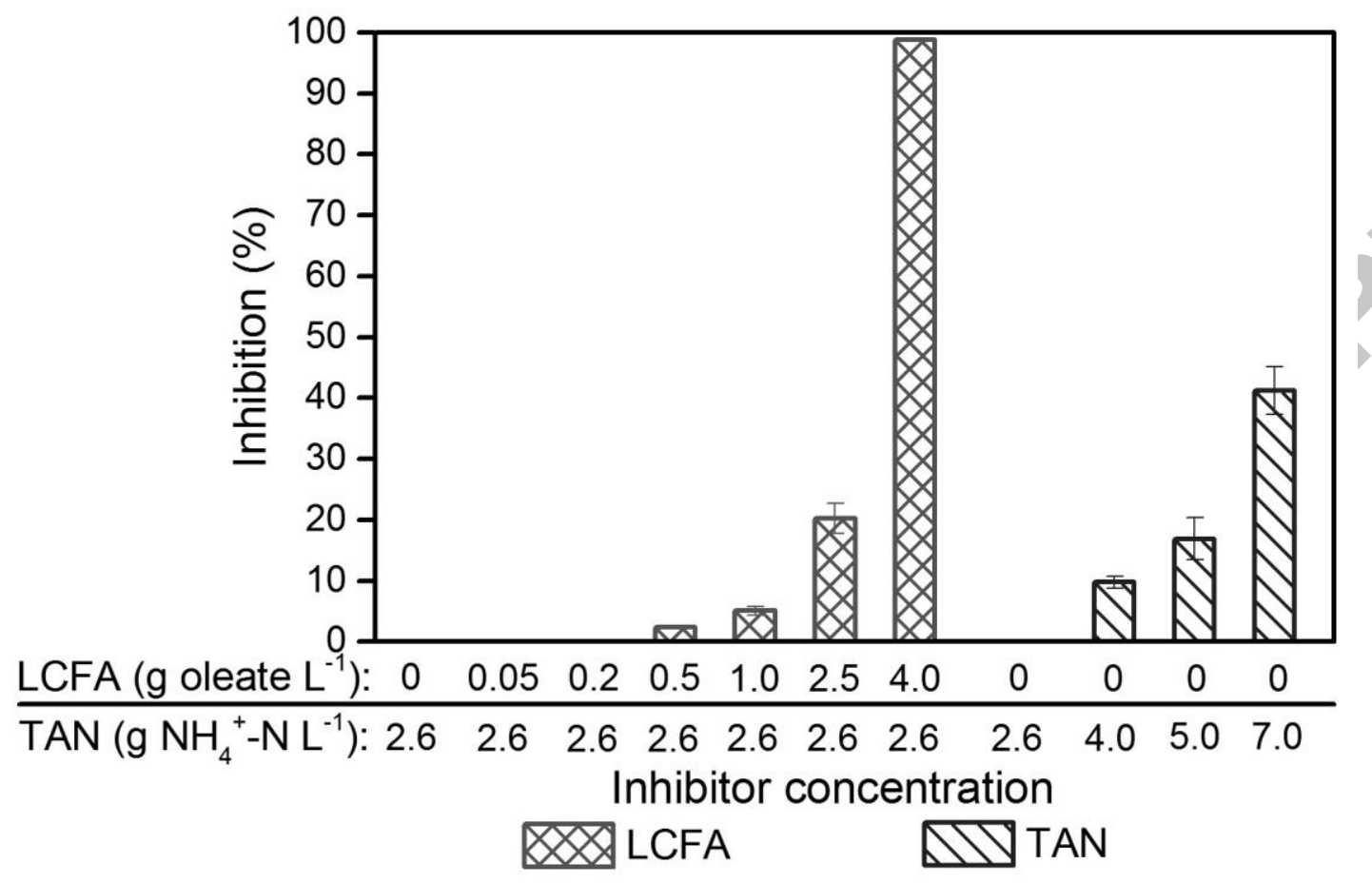




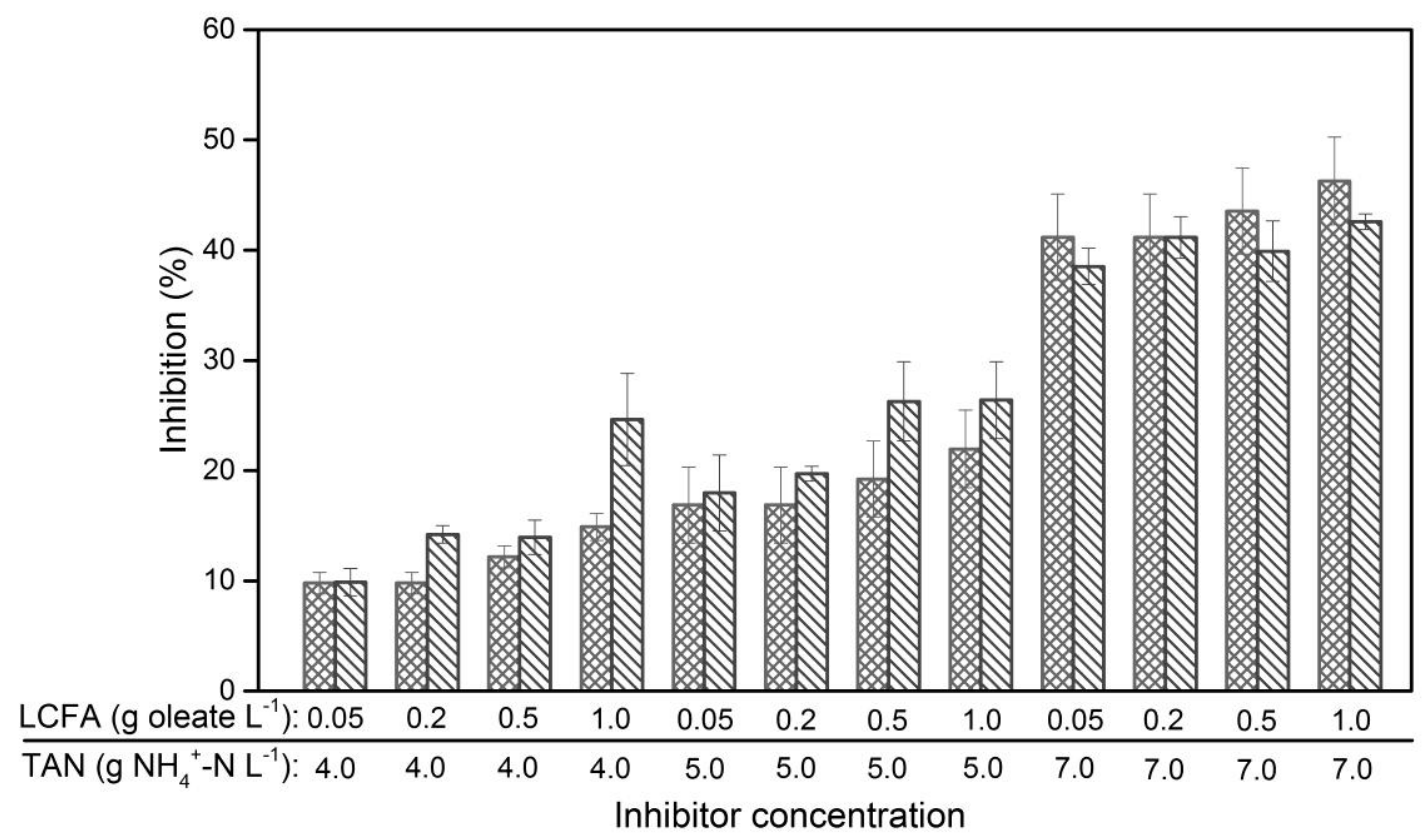

Theoretically expected inhibition $\mathbb{M}$ Experimentally practical inhibition 


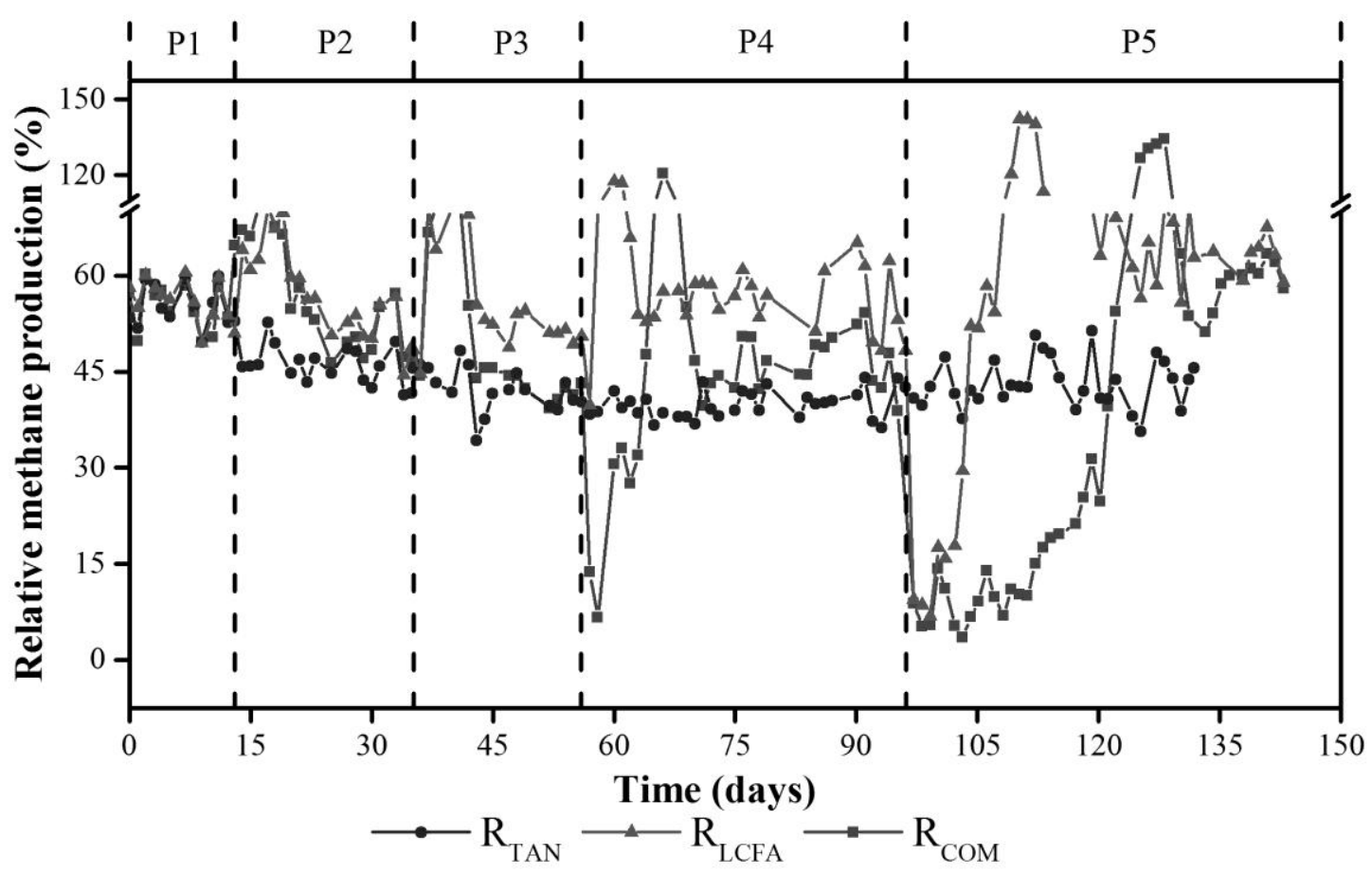




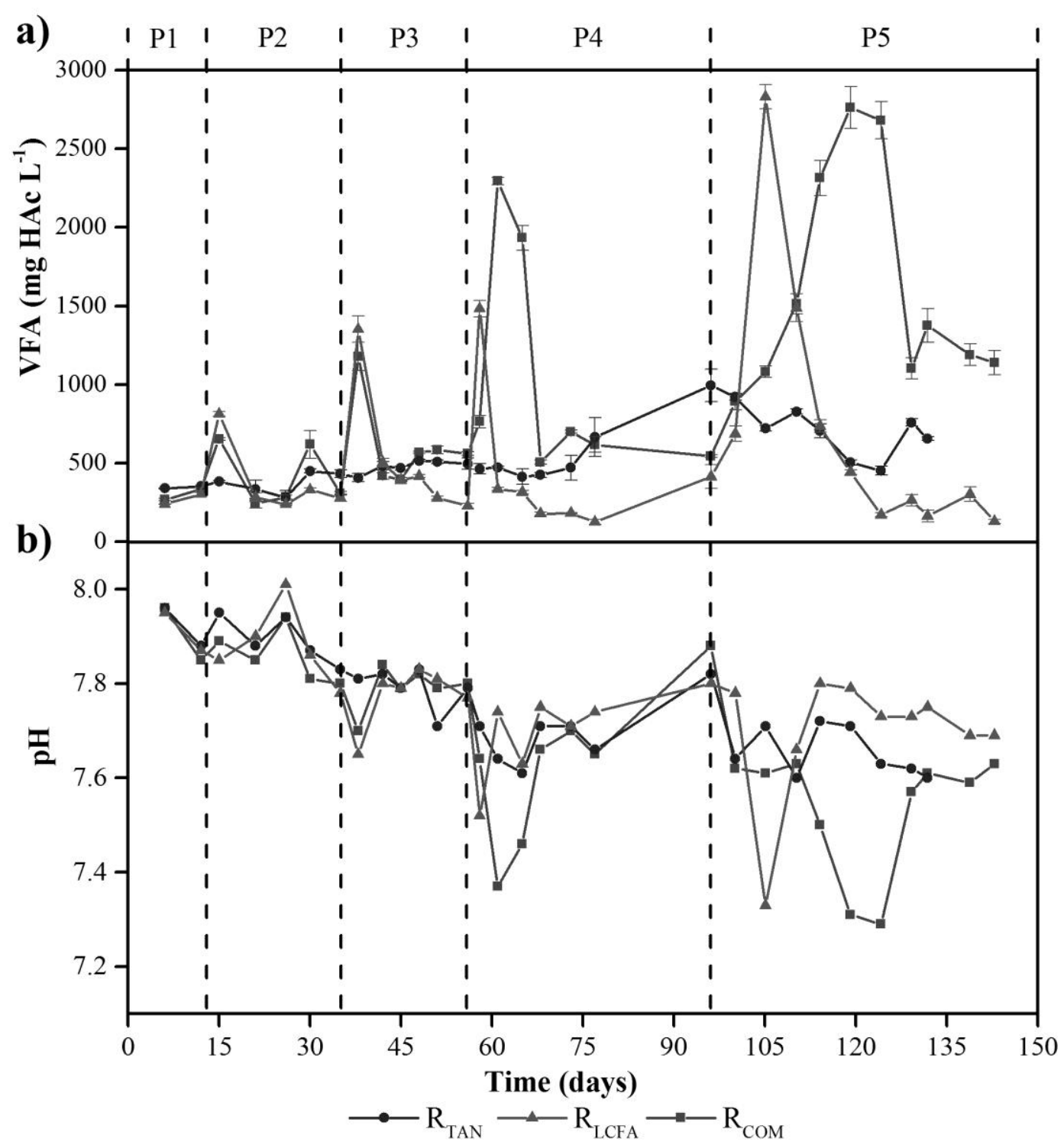



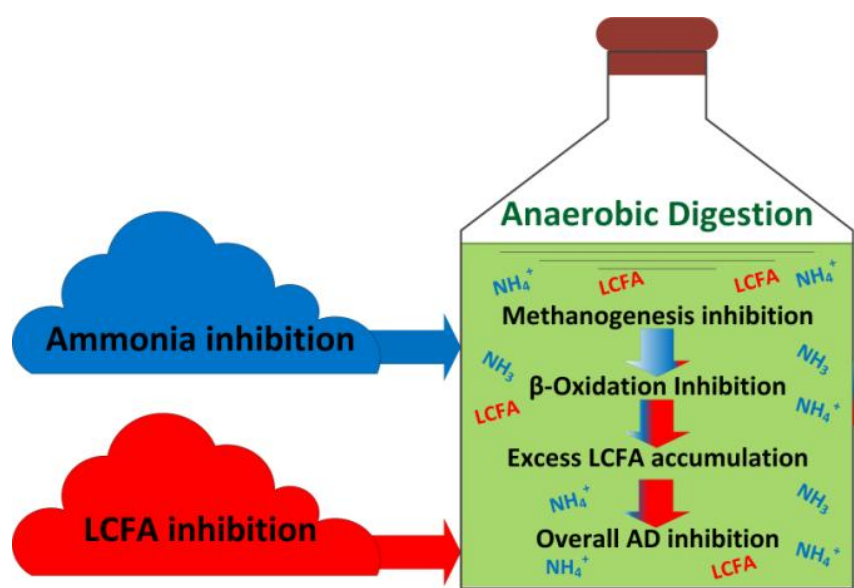

\section{Synergetic}

co-inhibition effect $\mathrm{NH}_{4}^{+}$ LCFA 


\section{Figure Legends}

Fig. 1. Individual inhibition (\%) of ammonia and LCFA under different TAN and LCFA levels.

Fig. 2. The theoretically expected and experimentally practical inhibition of the TAN+LCFA synergistic co-inhibition effect on the batch reactors.

Fig. 3. Relative methane production of the three CSTR reactors at different experimental phases.

Fig. 4. a) VFA accumulation and b) pH fluctuation of the three CSTR reactors at different phases. 


\section{Highlights}

- Identification of $\mathrm{NH}_{3}$-LCFA synergetic effect in batch and continuous reactors

- A new mechanism was proposed to explain the $\mathrm{NH}_{3}$-LCFA synergetic effect

- Excess LCFA levels due to $\beta$-oxidation inhibition by $\mathrm{NH}_{3}$ trigger the synergism

- Adaptation of the microbiome to the synergism is possible in continuous reactor

- Different $\mathrm{NH}_{3}$-LCFA levels cause the synergism in batch and continuous reactors 
Table 1. Characteristics of the inoculum and the substrate.

\begin{tabular}{lll}
\hline Parameter (unit) & Inoculum & Substrate \\
\hline Total solids-TS $\left(\mathrm{g} \mathrm{L}^{-1}\right)$ & $34.72 \pm 0.40^{*}$ & $35.84 \pm 0.14$ \\
Volatile solids-VS $\left(\mathrm{g} \mathrm{L}^{-1}\right)$ & $23.27 \pm 0.71$ & $25.42 \pm 0.18$ \\
Total Ammonium nitrogen-TAN $\left(\mathrm{g} \mathrm{NH}_{4}{ }^{+}-\mathrm{N} \mathrm{L}^{-1}\right)$ & $2.75 \pm 0.09$ & $1.48 \pm 0.01$ \\
Total Kjeldahl nitrogen-TKN $\left(\mathrm{g} \mathrm{N} \mathrm{L}^{-1}\right)$ & $2.77 \pm 0.10$ & $1.57 \pm 0.10$ \\
Volatile fatty acids-VFA $\left(\mathrm{mg} \mathrm{L}^{-1}\right)$ & $76.45 \pm 1.63$ & $2147.77 \pm 128.38$ \\
$\mathrm{pH}$ & 8.40 & 7.55 \\
\hline
\end{tabular}

* Standard deviation 
Table 2. Experimental setup of different TAN and LCFA levels of the three batch reactor assays

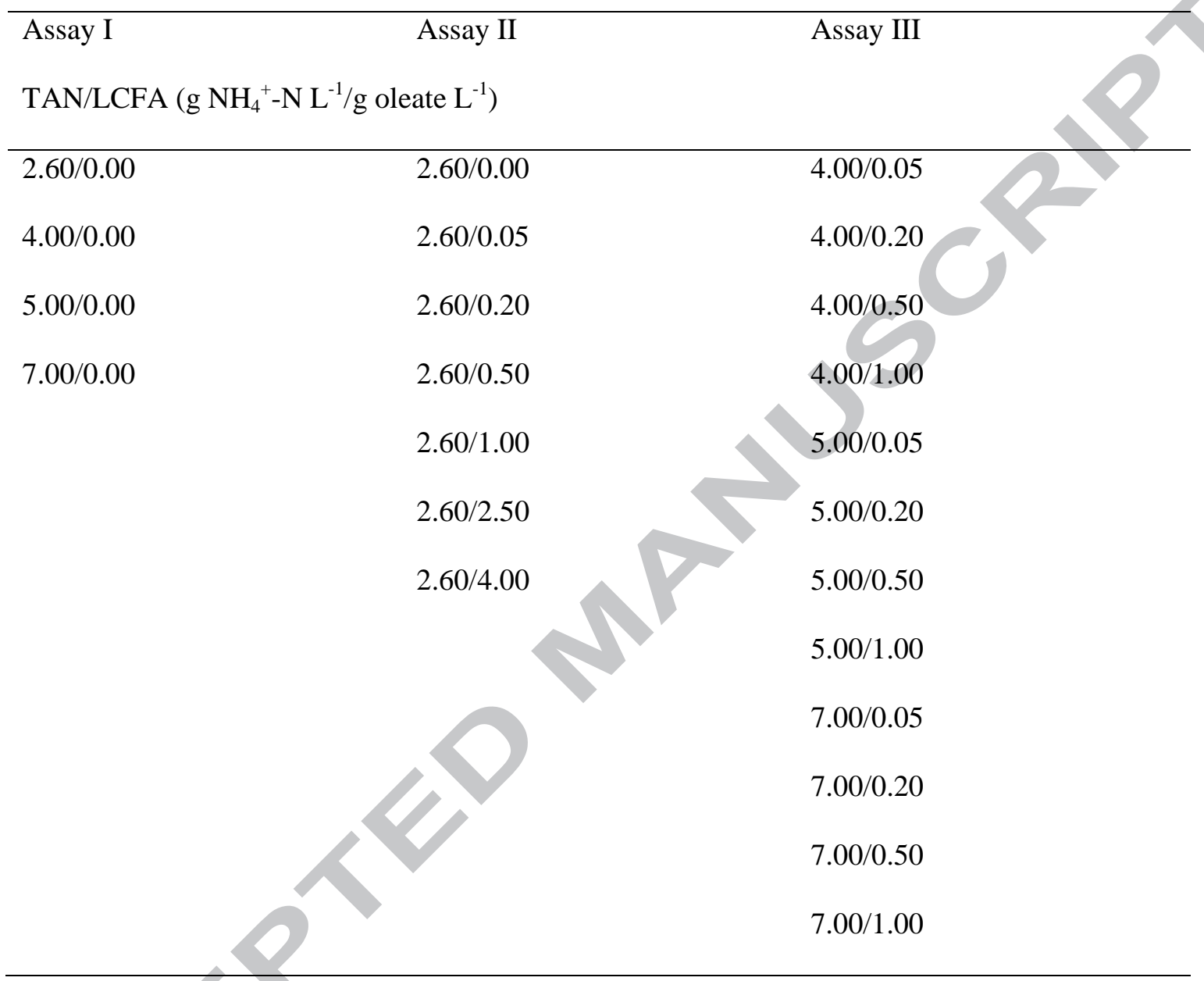


Table 3. Operational parameters in different experimental phases of the CSTR reactor experiment.

\begin{tabular}{|c|c|c|c|c|}
\hline & & $\mathrm{R}_{\mathrm{TAN}}$ & $\mathrm{R}_{\mathrm{LCFA}}$ & $\mathrm{R}_{\mathrm{COM}}$ \\
\hline Phases & Days & \multicolumn{3}{|c|}{ TAN/ LCFA $\left(\mathrm{g} \mathrm{NH}_{4}^{+}-\mathrm{N} \mathrm{L}^{-1} / \mathrm{g}\right.$ oleate $\left.\mathrm{L}^{-1}\right)$} \\
\hline Phase 1 (P1) & $0-12$ & $2.60 / 0$ & $2.60 / 0$ & $2.60 / 0$ \\
\hline Phase 2 (P2) & $13-35$ & $3.26 / 0$ & $2.60 / 0.42$ & $3.26 / 0.42$ \\
\hline Phase 3 (P3) & $36-56$ & $3.82 / 0$ & $2.60 / 0.7$ & $3.82 / 0.77$ \\
\hline Phase 4 (P4) & $57-96$ & $4.54 / 0$ & $2.60 / 1.13$ & $4.54 / 1.13$ \\
\hline Phase 5 (P5) & $97-143$ & $5.58 / 0$ & $2.60 / 2.18$ & $5.58 / 2.18$ \\
\hline
\end{tabular}

